\title{
Influence of Supplementation of Lactoferrin, Melittin and Cecropin A to Rat Diet on Changes in Faecal Ammonia Concentrations, Short-Chain Fatty Acid Concentrations and Activities of Bacterial Enzymes
}

\author{
Jerzy Juśkiewicz $^{1, *}$, Aleksandra Rawicka ${ }^{2}$, Bartosz Fotschki $^{1}{ }^{\circledR}$, Michał Majewski $^{3} \oplus$ and Zenon Zduńczyk ${ }^{1}$ \\ 1 Institute of Animal Reproduction and Food Research, Department of Biological Function of Food, \\ Polish Academy of Sciences, 10-748 Olsztyn, Poland; b.fotschki@pan.olsztyn.pl (B.F.); \\ z.zdunczyk@pan.olsztyn.pl (Z.Z.) \\ 2 Policlinico Veterinario Roma Sud, Ophthalmology, 00173 Rome, Italy; o.wiczkowska@gmail.com \\ 3 Department of Pharmacology and Toxicology, Faculty of Medicine, University of Warmia and Mazury, \\ 10-082 Olsztyn, Poland; michal.majewski@uwm.edu.pl \\ * Correspondence: j.juskiewicz@pan.olsztyn.pl; Tel.: +48-89-523-4673
}

Citation: Juśkiewicz, J.; Rawicka, A.; Fotschki, B.; Majewski, M.; Zduńczyk, Z. Influence of Supplementation of Lactoferrin, Melittin and Cecropin A to Rat Diet on Changes in Faecal Ammonia Concentrations, ShortChain Fatty Acid Concentrations and Activities of Bacterial Enzymes. Animals 2021, 11, 1203. https://doi. org/10.3390/ani11051203

Academic Editor: José Francisco Pérez

Received: 17 March 2021

Accepted: 21 April 2021

Published: 22 April 2021

Publisher's Note: MDPI stays neutral with regard to jurisdictional claims in published maps and institutional affiliations.

Copyright: (c) 2021 by the authors. Licensee MDPI, Basel, Switzerland. This article is an open access article distributed under the terms and conditions of the Creative Commons Attribution (CC BY) license (https:/ / creativecommons.org/licenses/by/ $4.0 /)$.
Simple Summary: In the present study conducted on Wistar laboratory rats, the effects of two selected insect antimicrobial peptides (AMPs), melittin and cecropin A, were investigated and compared to those attributed to well-known antibacterial action of lactoferrin. It was hypothesised that the dietary presence of lactoferrin, melittin or cecropin A strongly affects the rat large gut microbial activity at the time of protein/peptide administration and the durability of the effects may differ after their withdrawal from a diet. The experiment was conducted on living animals (without their euthanasia) and the dynamics of changes in $\mathrm{pH}$, microbial enzyme activity, ammonia and short-chain fatty acids concentrations were investigated in the faeces during and after the dietary treatments with lactoferrin, melittin or cecropin A. The results suggested that the faecal intensity of microbial fermentation processes in rats was quickly reduced upon dietary addition of two AMPs and lactoferrin after two days of treatment, on average. The strongest suppression effect was observed on the 5 th day of treatment and persisted on days 5-8. The changes caused by the supplemented lactoferrin and AMPs were reversible after 15 days, i.e., 10 days after the withdrawal of lactoferrin, melittin and cecropin A from the diet.

Abstract: We hypothesised that the dietary addition of the bioactive antimicrobial protein lactoferrin (LF) and peptides melittin (MT) or cecropin A (CR) at a dosage of $100 \mathrm{mg} / \mathrm{kg}$ to the diet of Wistar rats would result in strong modulatory effects on faecal microbial enzymatic activity, short-chain fatty acid and ammonia concentrations. To date, the changes in bacterial extracellular and intracellular enzymatic activities upon addition of dietary AMPs have not yet been studied. This experiment lasted 15 days; during the first 5 day period, the rats were fed the control diet $(S)$ and diets supplemented with LF, MT or CR. On days 6-15, all rats were fed the control S diet. The faecal fermentation processes were substantially stopped after two days of treatment, on average, in all rats receiving LF and two AMPs. The deepest suppression effect was observed on the last day of treatment (day 5) and persisted through days $5-8$. The highest decreases in faecal bacterial $\beta$-glucosidase and $\beta$ glucuronidase activities as well as in SCFA and ammonia concentrations were observed in the rats fed the CR diet. Only in the CR animals did the mechanism of suppressed microbial fermentation involve diminished enzyme release from bacterial cells to the digesta.

Keywords: antimicrobial peptides; melittin; cecropin A; lactoferrin; faeces; bacterial enzymes; shortchain fatty acids; ammonia; rat 


\section{Introduction}

Antimicrobial peptides (AMPs) are natural components of innate immunity in plants, fungi, bacteria and animals [1]. These small molecules (generally 2-50 kDa) serve as potent tools for controlling the number and activity of pathogens and natural microorganisms. AMPs are rapidly produced by the host in exposed tissues (skin, lungs, intestine, blood) at the time of contact with pathogens, but they are also stored as an emergency supply in cells [2]. It has been reported that insects, as organisms strongly resistant to invading bacteria, are able to produce massive amounts of AMPs at the time of danger [3]. Insect AMPs are classified into three types: $\alpha$-helical, $\beta$-sheet cysteine-rich and linear-extended peptides. Cecropins and cecropin-like peptides form the most abundant family of $\alpha$-helical AMPs with relatively high in vitro antimicrobial activity against Gram-negative bacteria and, to a lesser extent, against Gram-positive bacteria [4]. Interestingly, cecropins have been supposed to exhibit weak toxicity against normal mammalian cells and almost no effect on haemolysis in erythrocytes [5]. cecropin A, one of the well-researched cecropins, was first discovered in Hyalophora cecropia and has been used as a template for peptide molecular hybrids such as melittin [6]. Despite in vitro-derived knowledge, little is known about the in vivo effects of cecropin A on gut microbiota [4]. Regarding melittin, a polypeptide that constitutes half of dry honeybee venom, although much is known about its strong interaction with lipid membranes leading to increased permeability of erythrocytes and other cell membranes, less is known about how it affects the metabolism of the intestinal microbiota [7]. It has been predicted that these small peptide molecules may destroy bacterial cells by membrane and cytoplasmic component disruption and/or by interference with some metabolic pathways [8]. For instance, AMPs can demolish intracellular enzymes and DNA when entering the pathogen [9]. The relationship between ingested antibacterial agents and the gut microbiome is typically characterised by a double-face effect, with possible adverse effects from one side and with possible beneficial application from the other side. In our recent study [10], an analysis of bacterial enzymatic activity in rat caecal digesta revealed that lower short-chain fatty acid (SCFA) concentrations in the presence of antibacterial nanoparticles could be attributed to significantly diminished bacterial total enzymatic activity, including both extracellular and intracellular activities. The extracellular activity of bacterial enzymes has direct implications for the rate at which nutrients and non-nutrients undergo microbial digestion in the large intestine. Extracellular enzyme activity is influenced by the type and number of bacterial species present in the intestinal/faecal digesta and by the rate of enzyme secretion by bacterial cells. Gugolek et al. [11] reported that an elevated extracellular activity of glycoside hydrolases in relation to the total (sum of extra- and intracellular) activity of those enzymes could be an important adaptive mechanism of bacteria living in unfavourable intestinal environments. To the best of our knowledge, the changes in bacterial extracellular and intracellular enzymatic activities upon dietary AMPs have not yet been extensively studied. Taking that into account, the effects of two selected insect AMPs, melittin and cecropin A, were investigated and compared to those attributed to the well-known antibacterial action of lactoferrin. Lactoferrin is present in higher quantities in saliva, tears, seminal fluid, white blood cells and the milk of mammals [12]. It has been revealed that lactoferrin has bacteriostatic properties against Gram-negative bacteria requiring high iron, such as coliforms [13].

In the present study, it was hypothesised that the dietary presence of the antimicrobial protein-lactoferrin — and antimicrobial peptides-melittin or cecropin A-would strongly affect rat large gut microbial activity at the time of their administration and that the durability of the effects may differ after their withdrawal from a diet. The main intestinal segment of microbial fermentation processes in rats is the caecum. The measurements of caecal parameters would involve animal euthanasia, therefore with respect to 3Rs concept (replacement, reduction and refinement), the dynamics of changes in $\mathrm{pH}$, microbial enzyme activity, ammonia and short-chain fatty acid concentrations were investigated in the faeces during and after dietary treatments with lactoferrin and the antimicrobial peptides (melittin or cecropin A). 


\section{Materials and Methods}

\subsection{Antimicrobial Peptides and Lactoferrin}

Lactoferrin, melittin and cecropin A were purchased from Sigma-Aldrich Co. (Poznań, Poland). The purity of the preparations (according to the manufacturer) was L4765 Lactoferrin $\geq 85 \%$ (SDS-PAGE), M2272 Melittin $\geq 85 \%$ (HPLC) and C6830 cecropin A $\geq$ 97\% (HPLC).

\subsection{In Vivo Experiment}

The in vivo experiment was conducted on 32 adult, male, Wistar outbred rats (Rattus norvegicus, Cmdb:WI). The animals were used in compliance with the European Guidelines for the Care and Use of Laboratory Animals [14]. The experimental protocol was permitted by the Local Animal Care and Use Committee (Approval No. 34/2019; Olsztyn, Poland). All efforts were made to minimise experimental animal suffering. Two weeks before the start of the experiment, the rats were fed a standard non-supplemented diet prepared on a laboratory scale based on the recommendation of AIN-1993 [15]. The diet contained 20\% casein (Lacpol Co., Murowana Goślina, Poland), 0.3\% DL-methionine (SIGMA, Poznań, Poland), $0.3 \%$ cholesterol, $0.2 \%$ choline chloride, $8 \%$ rapeseed oil, $8 \%$ cellulose, standard mineral and vitamin mixes (3.5 and 1\%, respectively; according to AIN-93 requirements of laboratory adult rats), and corn starch to total $100 \%$. That diet was also used as a control dietary treatment (S group; Table 1).

Table 1. Composition of control (S) and experimental diets supplemented with lactoferrin (LF), melittin (MT) or cecropin A (CR).

\begin{tabular}{|c|c|c|c|c|}
\hline Ingredient (\%) & S & LF & MT & CR \\
\hline Casein ${ }^{1}$ & 20 & 20 & 20 & 20 \\
\hline DL-methionine & 0.3 & 0.3 & 0.3 & 0.3 \\
\hline Choline chloride & 0.2 & 0.2 & 0.2 & 0.2 \\
\hline Saccharose & 10 & 10 & 10 & 10 \\
\hline Cellulose & 8.0 & 8.0 & 8.0 & 8.0 \\
\hline Rapeseed oil & 8.0 & 0 & 0 & 0 \\
\hline Rapeseed oil with lactoferrin ${ }^{2}$ & 0 & 8.0 & 0 & 0 \\
\hline Rapeseed oil with melittin ${ }^{3}$ & 0 & 0 & 8.0 & 0 \\
\hline Rapeseed oil with cecropin $\mathrm{A}^{4}$ & 0 & 0 & 0 & 8.0 \\
\hline Cholesterol & 0.3 & 0.3 & 0.3 & 0.3 \\
\hline Mineral mix 5 & 3.5 & 3.5 & 3.5 & 3.5 \\
\hline Vitamin mix 6 & 1.0 & 1.0 & 1.0 & 1.0 \\
\hline Maize starch ${ }^{7}$ & 48.7 & 48.7 & 48.7 & 48.7 \\
\hline
\end{tabular}

${ }^{1}$ Casein preparation: crude protein $89.7 \%$, crude fat $0.3 \%$, ash $2.0 \%$, and water $8.0 \% .{ }^{2}$ Lactoferrin, SIGMA (L4765, Poznań, Poland), $\geq 85 \%$ (SDS-PAGE). ${ }^{3}$ Mellitin, SIGMA (M2272, Poznań, Poland), $\geq 85 \%$ (HPLC). ${ }^{4}$ cecropin A, SIGMA (C6830, Poznań, Poland), $\geq 97 \%$ (HPLC). ${ }^{5}$ AIN-93G-MX, per kg mix: $357 \mathrm{~g}$ calcium carbonate anhydrous $(40.04 \% \mathrm{Ca}), 196 \mathrm{~g}$ potassium phosphate monobasic $(22.76 \% \mathrm{P}$, $28.73 \% \mathrm{~K}), 70.78 \mathrm{~g}$ potassium citrate, tripotassium monohydrate $(36.16 \% \mathrm{~K}), 74 \mathrm{~g}$ sodium chloride $(39.34 \% \mathrm{Na}, 60.66 \% \mathrm{Cl}), 46.6 \mathrm{~g}$ potassium sulfate $(44.87 \% \mathrm{~K}, 18.39 \% \mathrm{~S}), 24 \mathrm{~g}$ magnesium oxide $(60.32 \% \mathrm{Mg}), 6.06 \mathrm{~g}$ ferric citrate $(16.5 \% \mathrm{Fe}), 1.65 \mathrm{~g}$ zinc carbonate $(52.14 \% \mathrm{Zn}), 1.45 \mathrm{~g}$ sodium meta-silicate $\times 9 \mathrm{H} 2 \mathrm{O}(9.88 \% \mathrm{Si}), 0.63 \mathrm{~g}$ manganous carbonate $(47.79 \% \mathrm{Mn}), 0.3 \mathrm{~g}$ cupric carbonate $(57.47 \% \mathrm{Cu}), 0.275 \mathrm{~g}$ chromium potassium sulfate $\times 12 \mathrm{H} 2 \mathrm{O}(10.42 \% \mathrm{Cr}), 81.5 \mathrm{mg}$ boric acid $(17.5 \% \mathrm{~B}), 63.5 \mathrm{mg}$ sodium fluoride $(45.24 \% \mathrm{~F}), 31.8 \mathrm{mg}$ nickel carbonate $(45 \%$ $\mathrm{Ni}), 17.4 \mathrm{mg}$ lithium chloride (16.38\% Li), $10.25 \mathrm{mg}$ sodium selenate anhydrous $(41.79 \% \mathrm{Se}), 10 \mathrm{mg}$ potassium iodate $(59.3 \% \mathrm{I}), 7.95 \mathrm{mg}$ ammonium paramolybdate $\times 4 \mathrm{H} 2 \mathrm{O}(54.34 \% \mathrm{Mo}), 6.6 \mathrm{mg}$ ammonium vanadate $(43.55 \% \mathrm{~V}), 221.026$ g powdered sucrose. ${ }^{6}$ AIN-93G-VM, $\mathrm{g} / \mathrm{kg}$ mix: 3.0 nicotinic acid, 1.6 Ca pantothenate, 0.7 pyridoxine- $\mathrm{HCl}, 0.6$ thiamin- $\mathrm{HCl}, 0.6$ riboflavin, 0.2 folic acid, 0.02 biotin, 2.5 vitamin B-12 (cyanocobalamin, $0.1 \%$ in mannitol), 15.0 vitamin E (all-rac- $\alpha$-tocopheryl acetate, $500 \mathrm{IU} / \mathrm{g}$ ), 0.8 vitamin A (all-trans-retinyl palmitate, 500,000 IU/g), 0.25 vitamin D-3 (cholecalciferol, 400,000 IU/g), 0.075 vitamin K-1 (phylloquinone), 974.655 powdered sucrose. ${ }^{7}$ Maize starch preparation: crude protein $0.6 \%$, crude fat $0.9 \%$, ash $0.2 \%$, total dietary fibre $0 \%$, and water $8.8 \%$.

The rats were similar in body weight $(\mathrm{BW})$ values $(285 \pm 11.6 \mathrm{~g})$ and were kept individually in metabolic cages (Tecnipalst, Buguggiate, Italy), enabling faecal sample collection. The feeding experiment lasted 15 days and comprised two periods: 5 days and 10 days. During the first 5 day period, the rats were subjected to four dietary treatments, i.e., control (S) without any supplementation; LF, supplemented with lactoferrin $(100 \mathrm{mg} / \mathrm{kg})$; MT, supplemented with melittin $(100 \mathrm{mg} / \mathrm{kg})$; and CR, supplemented with cecropin A 
$(100 \mathrm{mg} / \mathrm{kg})$. To evenly blend the peptide preparation with other diet components, the peptide was added along with rapeseed oil (Table 1). A fresh diet was served daily ad libitum, and access to water was continuous. In the second 10-day period, all rats were treated with the control diet. Standard conditions at $21-22{ }^{\circ} \mathrm{C}$ and relative air humidity of $50 \%$ with intensive room ventilation $(15 \times$ per $\mathrm{h})$ and a $12 \mathrm{~h}$ light $/ 12 \mathrm{~h}$ dark regimen was applied. During the entire feeding period, from 6.00 p.m. -9.00 p.m. on days $0,1,2,5$, $6,8,10$ and 15 , rat faeces were thoroughly collected and subjected to the analyses as soon as possible. The daily consumed dosage of the LF, MT and CR per rat was $7 \mathrm{mg} / \mathrm{kg}$ of BW, and it reflected a daily ingestion of $85 \mathrm{mg}$ of the supplemented protein/peptide by an adult weighing $75 \mathrm{~kg}$ (calculated with the aid of the body surface area method [16]).

\subsection{Measurements and Analyses}

Samples of fresh faeces were combined in a porcelain laboratory mortar and then used for the following analyses: $\mathrm{pH}$, bacterial enzymatic activity and concentrations of ammonia and short-chain fatty acids (SCFAs). The faecal $\mathrm{pH}$ was measured immediately (three measurements per sample) using a microelectrode and a $\mathrm{pH} / \mathrm{ION}$ meter (model 301, Hanna Instruments, Vila do Conde, Portugal). Ammonia was extracted from fresh faeces, trapped in a solution of boric acid in Conway dishes and determined by direct titration with sulfuric acid [17]. The concentrations of SCFAs in the samples were analysed by gas chromatography (Shimadzu GC-2010, Kyoto, Japan). The samples $(0.2 \mathrm{~g})$ were mixed with $0.2 \mathrm{~mL}$ of formic acid, diluted with deionised water and centrifuged at $7211 \times \mathrm{g}$ for $10 \mathrm{~min}$. The supernatant was transferred to a vial and loaded onto a capillary column (SGE BP21, $30 \mathrm{~m} \times 0.53 \mathrm{~mm}$ ) using an on-column injector. The initial oven temperature was $85^{\circ} \mathrm{C}$, and it was raised to $180^{\circ} \mathrm{C}$ in steps of $8^{\circ} \mathrm{C} / \mathrm{min}$ and maintained for $3 \mathrm{~min}$. The temperatures of the flame ionisation detector and the injection port were $180^{\circ} \mathrm{C}$ and $85^{\circ} \mathrm{C}$, respectively. The volume of the sample for gas chromatography was $1 \mu \mathrm{L}$. The concentrations of faecal putrefactive SCFAs (PSCFAs) were calculated as the sum of isobutyrate, isovalerate and valerate. All SCFA analyses were performed in duplicate. Pure acetic, propionic, butyric, iso-butyric, iso-valeric and valeric acids were obtained from Sigma (Poznan, Poland), and they were combined to create a standard plot and calculate the amount of each acid. The additional set of pure acids was included in each GC run at five sampling intervals to maintain calibration.

In addition to SCFA analysis, faecal fermentation processes were analysed based on the activity of selected bacterial enzymes ( $\alpha$ - and $\beta$-glucosidase, $\beta$-glucuronidase), which was measured by the rate of release of p-nitrophenol from the respective nitrophenylglucosides, according to a previously described method [18]. The following substrates were used: $\mathrm{p}$ nitrophenyl- $\alpha$-D-glucopyranoside (for $\alpha$-glucosidase), p-nitrophenyl- $\beta$-D-glucopyranoside (for $\beta$-glucosidase) and $\mathrm{p}$-nitrophenyl- $\beta$-D-glucuronide (for $\beta$-glucuronidase). The activity of enzymes secreted by bacterial cells in the faecal environment was measured by preparing a reaction mixture containing $0.3 \mathrm{~mL}$ of the substrate solution $(5 \mathrm{mM})$ and $0.2 \mathrm{~mL}$ of a 1:10 (v/v) dilution of the faecal sample in $100 \mathrm{mM}$ phosphate buffer ( $\mathrm{pH} 7.0)$, which was centrifuged at $7211 \times g$ for $15 \mathrm{~min}$. Incubation was carried out at $37^{\circ} \mathrm{C}$, and p-nitrophenol was quantified at $400 \mathrm{~nm}$ after the addition of $2.5 \mathrm{~mL}$ of $0.25 \mathrm{M}$ cold sodium carbonate. Enzyme activity was expressed in $\mu \mathrm{mol}$ of the product formed per hour per gram of fresh faeces. To determine the total activity of selected faecal bacterial enzymes, including extracellular activity (see the procedure above) and intracellular activity, a sample of faeces diluted in phosphate buffer was mechanically disrupted by vortexing with glass beads (212-300 $\mu \mathrm{m}$ in diameter; four periods of $1 \mathrm{~min}$ each, with 1 min cooling intervals on ice) in the FastPrep ${ }^{\circledR}-24$ homogenizer (MP Biomedicals, Santa Ana, CA, USA). The resulting mixture was centrifuged at $7211 \mathrm{~g}$ for $15 \mathrm{~min}$ at $4{ }^{\circ} \mathrm{C}$. The supernatant was used for the enzyme assay described above. Intracellular enzyme activity was calculated by comparing total enzyme activity with the activity of bacterial enzymes released into the faecal environment, and it was expressed in $\mu \mathrm{mol}$ of the product (PNP, p-nitrophenol) formed per hour per gram of faeces. The respective calculation formulas were derived 
based on the model curves for PNP (PNP standard solution in $100 \mathrm{mM}$ phosphate buffer, $\mathrm{pH} 7.0,40 \mathrm{mg} / \mathrm{L}$ ). Extracellular enzyme activity was also determined as the rate of enzyme release, and it was expressed as a percentage of total enzyme activity. All analyses were performed in duplicate.

\subsection{Statistical Analyses}

Data are expressed as the mean and pooled standard error of the mean (SEM). The results were analysed statistically by one-way ANOVA, and the significance of differences between groups was determined with the Tukey multiple range test at a significance level of $p \leq 0.05$. All calculations were performed with the aid of Statistica 12.0 software.

\section{Results}

\subsection{Faecal $\beta$-Glucosidase Activity}

After just one day of the treatment, the extracellular activity of faecal bacterial $\beta$ glucosidase was decreased by the CR diet compared to the control diet (Figure 1). The total activity, composed of extra- and intracellular activities, of that enzyme on day 1 was decreased by LF and two AMP treatments ( $p<0.05$ vs. S). The highest and lowest extracellular activity on day 2 was noted in the $S$ ( $p<0.05$ vs. remaining groups) and $C R$ $(p<0.05$ vs. S, LF) animals, respectively. On that day, the highest and lowest intracellular activity was in rats in the S, LF and MT groups ( $p<0.05$ vs. MT, CR and $p<0.05$ vs. S, $\mathrm{LF}, \mathrm{CR}$, respectively). The total activity of faecal bacterial $\beta$-glucosidase on day 2 was significantly reduced by LF and two AMPs compared to the control, but the strongest reduction was noted in the MT and CR rats ( $p<0.05$ vs. $S$ and LF). On day 2, the calculated release of enzymes was significantly diminished by the $C R$ treatment in comparison to the $S$ and MT treatments. After 5 days of feeding with diets containing LF and AMPs, the faeces of rats in the MT and CR groups were characterised by the lowest extracellular and total $\beta$-glucosidase activities $(p<0.05 \mathrm{vs.} S$ and LF), while the highest activities were attributed to the $S$ group ( $p<0.05$ vs. all remaining groups). For the intracellular activity on day 5 , the lowest value was in MT rats ( $p<0.05$ vs. S, LF), and the highest was in $S$ rats $(p<0.05$ vs. MT, CR). The percentage of enzyme release on day 5 was the highest and lowest in the MT and CR groups, respectively ( $p<0.05$ vs. LF, CR and $p<0.05$ vs. S, MT). On day 6 , the $S$ animals had the highest faecal total, extra- and intracellular activities of bacterial $\beta$-glucosidase ( $p<0.05$ vs. other groups); the lowest total activity was in the MT and CR rats, the lowest extracellular activity was in the CR group, and the lowest intracellular activity was in the MT group (in all cases $p<0.05$ vs. S and LF). The enzyme release value on day 6 was decreased by CR treatment compared to the $S$ and MT treatments. The highest and lowest values for extracellular activity, total activity and enzyme release of $\beta$-glucosidase on day 8 were noted in the $S$ and CR faeces (in all cases $p<0.05$ vs. other groups). On day 8 , the intracellular activity was diminished by the MT treatment $(p<0.05$ vs. $S$ and LF). The faeces of CR rats were characterised by decreased extracellular activity, total activity and enzyme release percentage on day 10 ( $p<0.05$ vs. S, LF and MT). On day 15 , the differences in assessed $\beta$-glucosidase indicators between groups were insignificant $(p>0.05)$. 


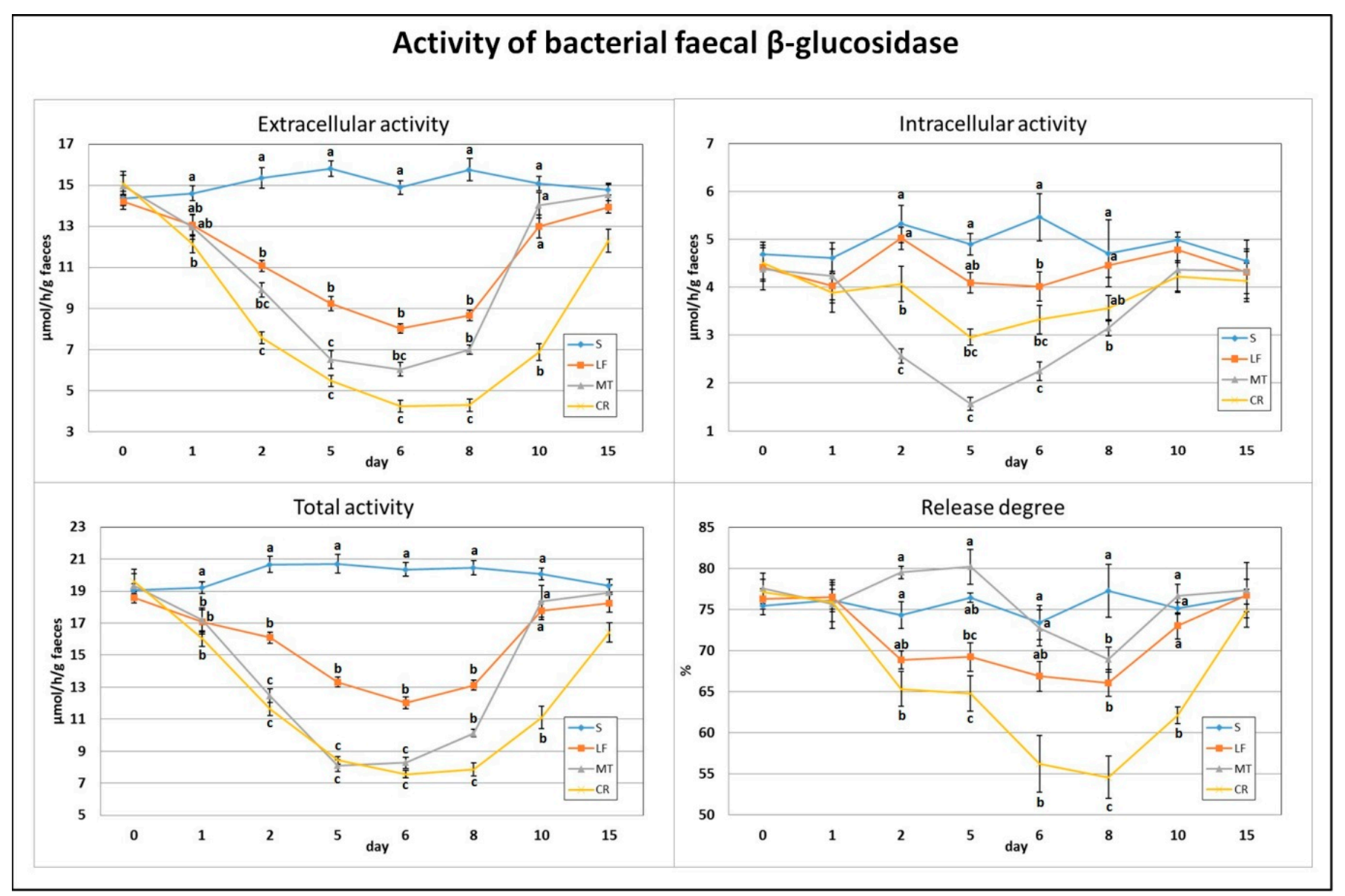

Figure 1. Experimental factor in particular groups: S—control standard diet (0-15 days); LF-standard diet with lactoferrin addition $100 \mathrm{mg} / \mathrm{kg}$ (0-5 days diet LF and 6-15 days diet S); MT—standard diet with melittin addition 100 mg/ $\mathrm{kg}$ (0-5 days diet MT and 6-15 days diet S); CR-standard diet with cecropin A addition $100 \mathrm{mg} / \mathrm{kg}$ (0-5 days diet CR and 6-15 days $\operatorname{diet} S) .{ }^{a, b, c}$ Mean values on the day with no common superscript are different at $p \leq 0.05$. Data are presented as the mean with SEM; SEM-SD for all rats divided by the square root of rat number in one group $(n=8)$. Release degree, extracellular expressed as percent of total activity.

\subsection{Faecal $\beta$-Glucuronidase Activity}

On day 2, a significant decrease in the total, extracellular and intracellular activities of bacterial faecal $\beta$-glucuronidase was found for all three dietary AMP treatments compared to the $S$ group (Figure 2). Similar decreases in the LF, MT and CR rats were observed on days 5 and 6. Additionally, on day 5, the MT and CR dietary treatments and, on day 6, only the CR treatment were accompanied by a higher drop in the total and extracellular activities ( $p<0.05$ vs. S and LF and $p<0.05$ vs. S, LF and MT, respectively). The CR group had a lower faecal $\beta$-glucuronidase release degree on days 5 and $6(p<0.05$ vs. S, LF and $p<0.05$ vs. S, respectively). On days 8 and 10, all three AMP treatments caused diminished total and extracellular activity in comparison to the $S$ treatment $(p<0.05)$. Additionally, on day 10, the CR treatment was associated with the lowest faecal total activity of bacterial $\beta$-glucuronidase $(p<0.05$ vs. S and LF). The percentage of enzyme release on day 8 was the lowest in the CR faeces ( $p<0.05$ vs. S). 


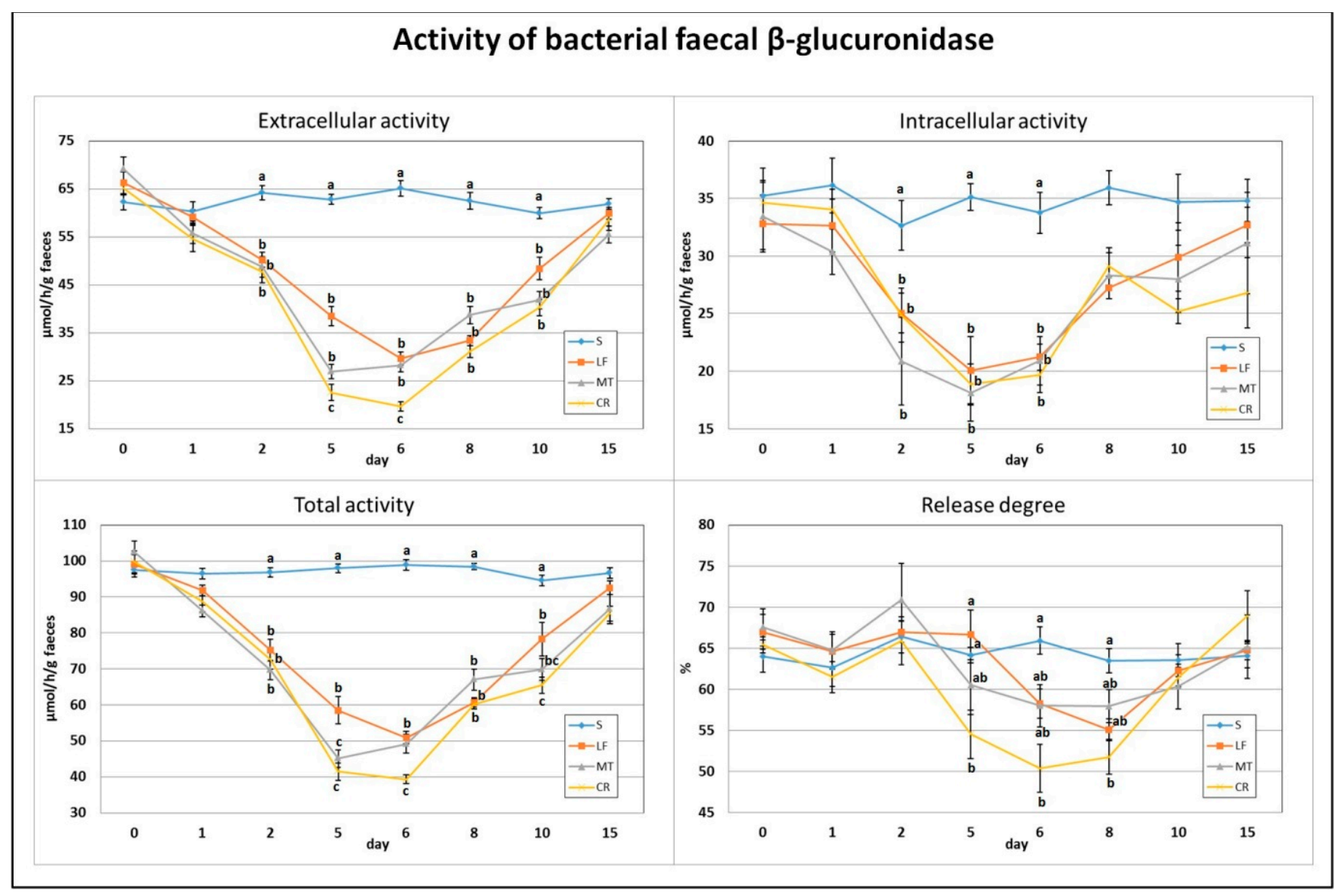

Figure 2. Experimental factor in particular groups: S—control standard diet (0-15 days); LF—standard diet with lactoferrin addition $100 \mathrm{mg} / \mathrm{kg}$ (0-5 days diet LF and 6-15 days diet S); MT—standard diet with melittin addition $100 \mathrm{mg} / \mathrm{kg}$ (0-5 days diet MT and 6-15 days diet S); CR—standard diet with cecropin A addition $100 \mathrm{mg} / \mathrm{kg}$ (0-5 days diet CR and 6-15 days $\operatorname{diet} S) .{ }^{a, b, c}$ Mean values on the day with no common superscript are different at $p \leq 0.05$. Data are presented as the mean with SEM; SEM-SD for all rats divided by the square root of rat number in one group $(n=8)$. Release degree, extracellular expressed as percent of total activity.

\subsection{Faecal $\alpha$-Glucosidase Activity}

The applied dietary addition of three AMPs, lactoferrin, melittin and cecropin A, resulted in a significant decrease in faecal total and extracellular activity of bacterial $\alpha$ glucosidase on days 2,5 and 6 ( $p<0.05 \mathrm{vs.} \mathrm{S;} \mathrm{Figure} 3$ ). In comparison to the $\mathrm{S}$ treatment, the calculated enzyme release percentage was diminished on day 2 in the CR treatment, on day 5 in the CR and LF treatments, and on day 6 in the CR, LF and MT treatments $(p<0.05)$. The lowest extracellular activity of faecal $\alpha$-glucosidase and its enzyme release percentage on day 8 were noted in the CR group (in both cases $p<0.05 \mathrm{vs}$. all remaining groups). Additionally, on that day, the LF rats had significantly lower extracellular activity than the $S$ rats fed the control diet. On day 10, the CR group had the lowest extracellular and the highest intracellular activities of faecal $\alpha$-glucosidase ( $p<0.05$ vs. $S$ and $p<0.05$ $\mathrm{S}$ and MT, respectively). The percentage of enzyme release on day 10 was significantly decreased by the CR treatment in comparison to the $S$ and MT treatments. 


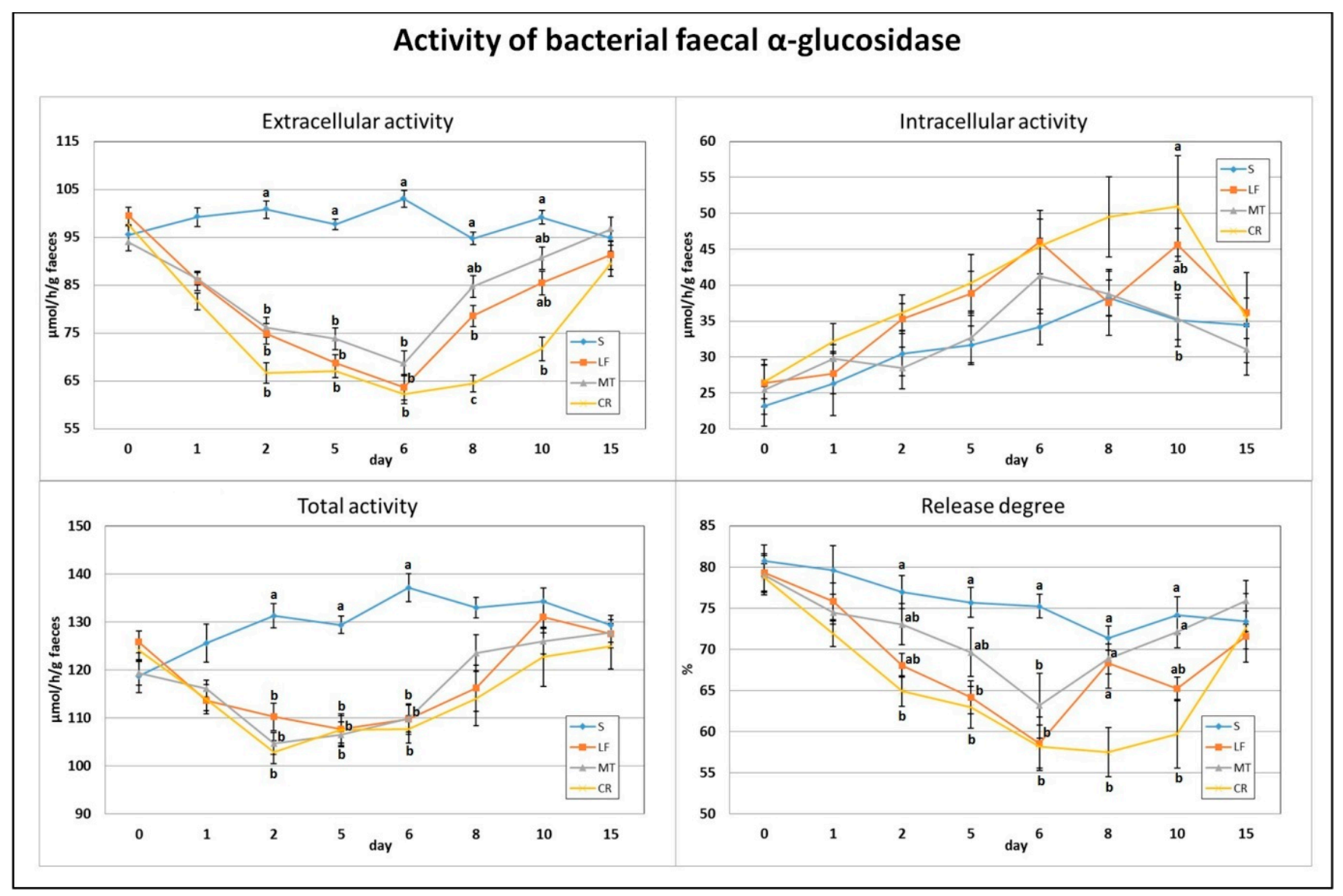

Figure 3. Experimental factor in particular groups: S—control standard diet (0-15 days); LF—standard diet with lactoferrin addition $100 \mathrm{mg} / \mathrm{kg}$ (0-5 days diet LF and 6-15 days diet S); MT—standard diet with melittin addition $100 \mathrm{mg} / \mathrm{kg}$ (0-5 days diet MT and 6-15 days diet S); CR—standard diet with cecropin A addition $100 \mathrm{mg} / \mathrm{kg}$ (0-5 days diet CR and 6-15 days $\operatorname{diet} S) .{ }^{a, b, c}$ Mean values on the day with no common superscript are different at $p \leq 0.05$. Data are presented as the mean with SEM; SEM-SD for all rats divided by the square root of rat number in one group $(n=8)$. Release degree, extracellular expressed as percent of total activity.

\subsection{Faecal SCFA Concentration}

As indicated in Figures 4 and 5, on day 2, the dietary treatments supplemented with LF, MT and CR caused a significant decrease in the faecal concentrations of acetic acid, butyric acid and total SCFAs in comparison to the control treatment. The propionic acid concentration was decreased by treatments LF and MT, and the faecal PSCFA concentration was decreased by treatments LF and CR compared to the $S$ treatment $(p<0.05)$. The lowest PSCFA level on day 2 was attributed to the CR treatment ( $p<0.05$ vs. all other groups). In comparison to the control group, the three supplemented AMP groups had decreased faecal concentrations for all analysed SCFAs on days 5 and 6, except for the butyric acid concentration in the faeces of the LF group and that in the faeces of the LF and MT groups, on those days respectively. On day 8, the three AMPs reduced the faecal concentration of PSCFAs, while the CR treatment decreased the total SCFA, acetic acid and propionic acid concentrations ( $p<0.05$ vs. $\mathrm{S}$ in all cases). The CR group on day 10 was characterised by the lowest faecal concentrations of propionic acid, total SCFAs ( $p<0.05$ vs. S) and faecal PSCFAs ( $p<0.05$ vs. S, LF, MT). 


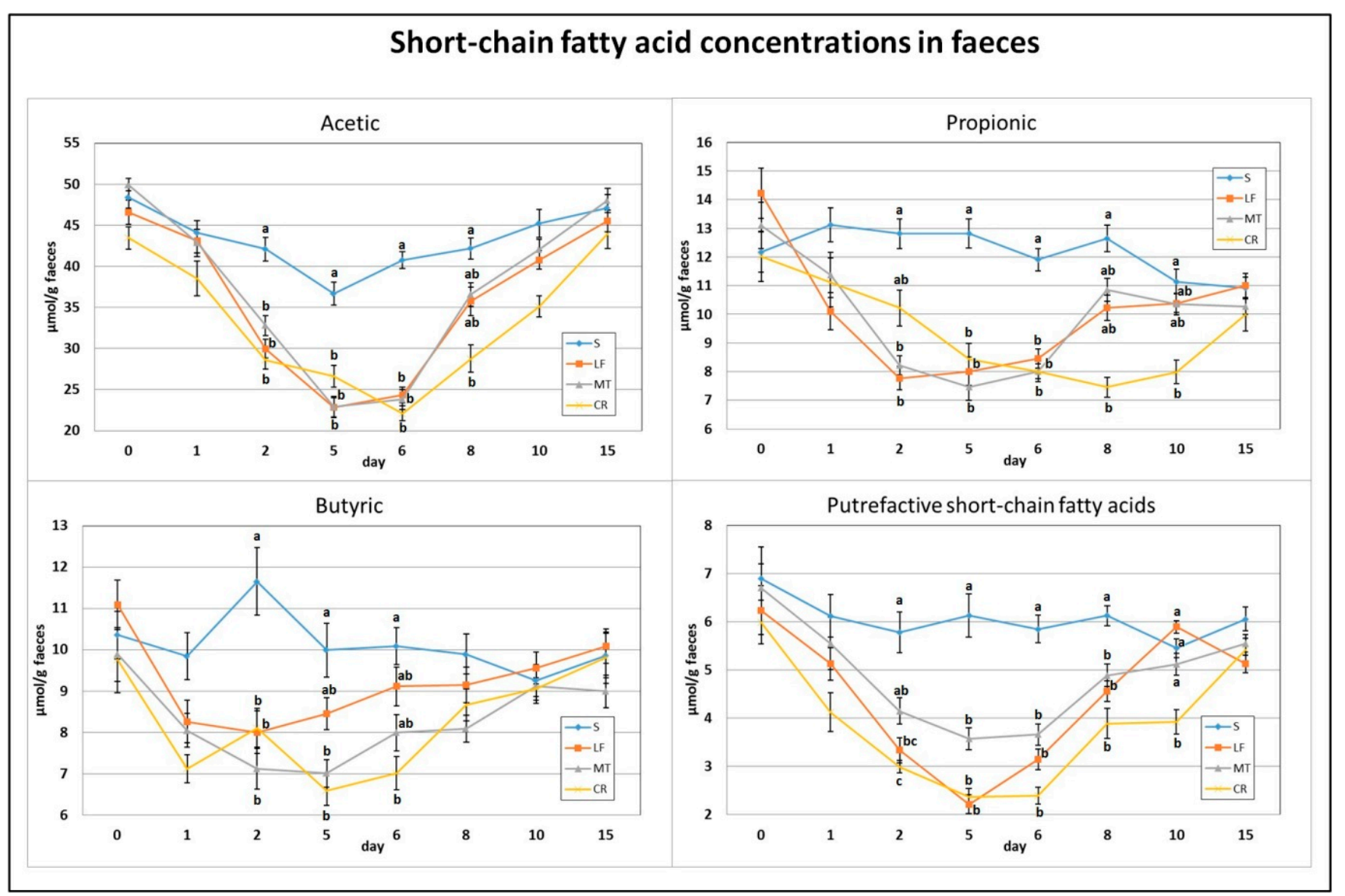

Figure 4. Experimental factor in particular groups: S—control standard diet (0-15 days); LF-standard diet with lactoferrin addition $100 \mathrm{mg} / \mathrm{kg}$ (0-5 days diet LF and 6-15 days diet S); MT—standard diet with melittin addition 100 mg/kg (0-5 days diet MT and 6-15 days diet S); CR-standard diet with cecropin A addition $100 \mathrm{mg} / \mathrm{kg}$ (0-5 days diet CR and 6-15 days diet $S)$. ${ }^{a, b, c}$ Mean values on the day with no common superscript are different at $p \leq 0.05$. Data are presented as the mean with SEM; SEM-SD for all rats divided by the square root of rat number in one group $(n=8)$.

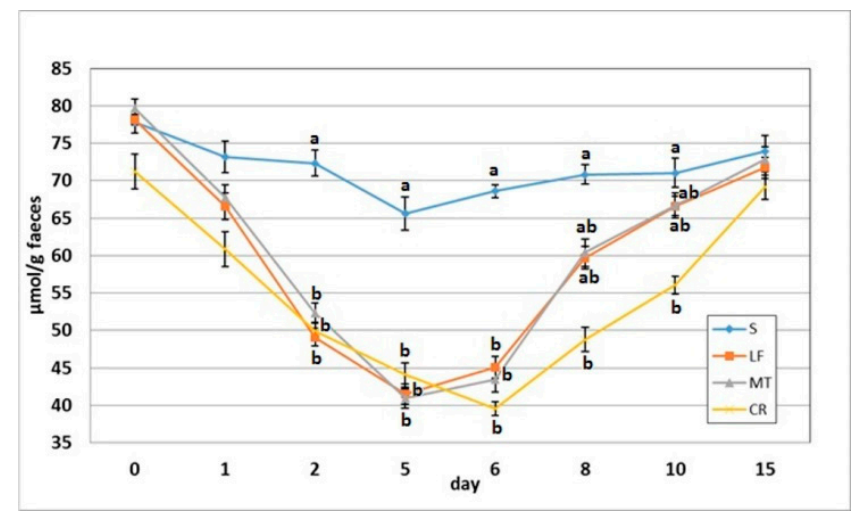

Figure 5. Total short-chain fatty acid concentration in faeces of rats fed diets supplemented with lactoferrin, melittin or cecropin A. Experimental factor in particular groups: S-control standard diet (0-15 days); LF-standard diet with lactoferrin addition $100 \mathrm{mg} / \mathrm{kg}$ (0-5 days diet LF and 6-15 days $\operatorname{diet} \mathrm{S})$; MT-standard diet with melittin addition $100 \mathrm{mg} / \mathrm{kg}$ (0-5 days diet MT and 6-15 days diet S); CR—standard diet with cecropin A addition $100 \mathrm{mg} / \mathrm{kg}$ (0-5 days diet CR and 6-15 days diet S). $\mathrm{a}, \mathrm{b}$ Mean values on the day with no common superscript are different at $p \leq 0.05$. Data are presented as the mean with SEM; SEM-SD for all rats divided by the square root of rat number in one group $(n=8)$. 


\subsection{Faecal $p H$ and Ammonia Concentration}

The dietary addition of LF resulted in a significant increase in the faecal $\mathrm{pH}$ on day 2 when compared to the $S$ group (Figure 6). The AMP experimental treatments LF, MT and $\mathrm{CR}$ elevated the faecal $\mathrm{pH}$ on days 5,6 and 8 compared with that of the control treatment $(p<0.05)$. The CR rats had increased faecal $\mathrm{pH}$ on day compared to the $\mathrm{S}, \mathrm{LF}$ and MT animals $(p<0.05)$. All rats had similar faecal $\mathrm{pH}$ values on day 15 within a relatively narrow range of 7.14-7.18. The faecal ammonia concentration on day 2 was significantly decreased in rats fed diets MT and CR compared to those fed diet S (Figure 7). The MT and CR groups had the lowest faecal ammonia concentrations on days 5 and $8(p<0.05$ vs. $S$ and LF), while the highest concentration on those days was noted in the $S$ group ( $p<0.05$ vs. remaining groups). The highest and lowest ammonia levels on day 6 were observed in the faeces of the $S$ and CR animals, respectively (in both cases $p<0.05$ vs. other groups). The three AMP treatments caused similar significant decreases on day 10 in the faecal ammonia concentration vs. the control treatment. On day 15, the differences in faecal ammonia between groups were insignificant $(p>0.05)$.

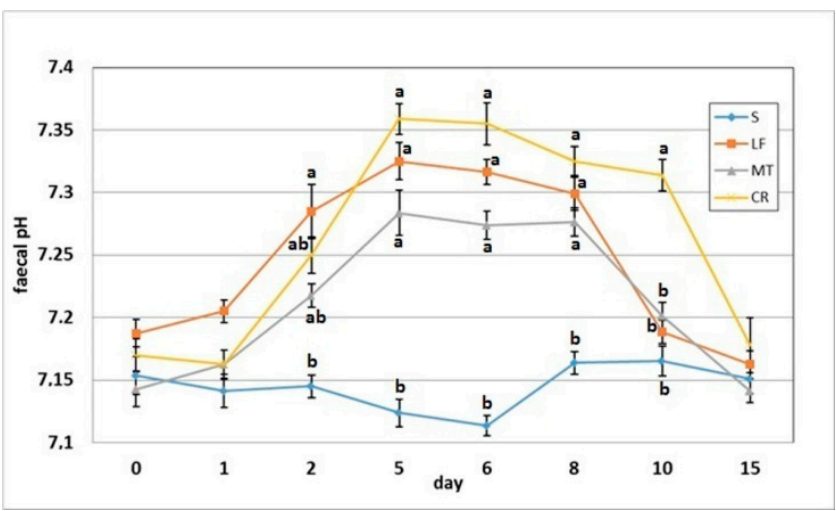

Figure 6. Faecal $\mathrm{pH}$ of rats fed diets supplemented with lactoferrin, melittin or cecropin A. Experimental factor in particular groups: S—control standard diet (0-15 days); LF—standard diet with lactoferrin addition $100 \mathrm{mg} / \mathrm{kg}$ (0-5 days diet LF and 6-15 days diet S); MT—standard diet with melittin addition $100 \mathrm{mg} / \mathrm{kg}$ (0-5 days diet MT and 6-15 days diet S); CR-standard diet with cecropin A addition $100 \mathrm{mg} / \mathrm{kg}$ (0-5 days diet CR and 6-15 days diet S). ${ }^{\mathrm{a}, \mathrm{b}}$ Mean values on the day with no common superscript are different at $p \leq 0.05$. Data are presented as the mean with SEM; SEM-SD for all rats divided by the square root of rat number in one group $(n=8)$.

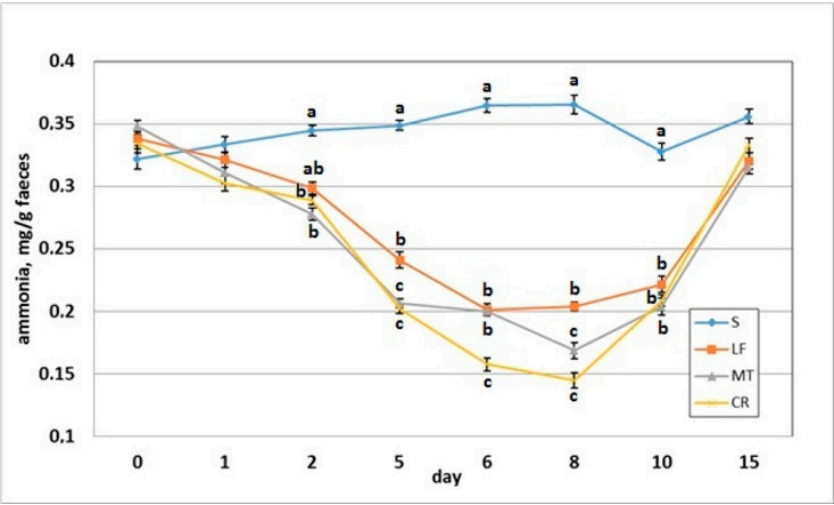

Figure 7. Faecal ammonia concentration of rats fed diets supplemented with lactoferrin, melittin or cecropin A. Experimental factor in particular groups: S—control standard diet (0-15 days); LFstandard diet with lactoferrin addition $100 \mathrm{mg} / \mathrm{kg}$ (0-5 days diet LF and 6-15 days diet S); MTstandard diet with melittin addition $100 \mathrm{mg} / \mathrm{kg}$ (0-5 days diet MT and 6-15 days diet S); CR-standard diet with cecropin A addition $100 \mathrm{mg} / \mathrm{kg}$ (0-5 days diet CR and 6-15 days diet $S$ ). ${ }^{\mathrm{a}, \mathrm{b}, \mathrm{c}}$ Mean values on the day with no common superscript are different at $p \leq 0.05$. Data are presented as the mean with SEM; SEM—SD for all rats divided by the square root of rat number in one group $(n=8)$. 


\section{Discussion}

In the present study, the faecal concentration of microbial fermentation end-products (short-chain fatty acids, ammonia) and the activity of selected bacterial enzymes were analysed instead of bacterial count. Of course, bacteriological investigations (e.g., identification of selected groups) should be regarded as useful in describing the basic ecology of the gut, but they do not describe and explain metabolic details that directly impact the health status of the host. Currently, modern research techniques allow us to conduct studies of the metabolome, i.e., the complete set of metabolites produced within an organism, but this is still an expensive and labour-intensive process [19]. An alternative approach is to use biochemical assays that measure the functional activity of the microbiota as a whole and thus permit deductions to be made regarding the role of the microbial community in the metabolism of dietary components. In addition, by selecting microbial enzyme activities or metabolic endpoints resulting in compounds with potentially toxic or beneficial effects, probable health consequences for the host can be assessed [20,21]. To better characterise the enzymatic action of the microbial community, in the present study, the extracellular, intracellular and total activities of bacterial enzymes were measured in the faecal environment. It has been reported that extracellular enzyme activity directly affects the rate at which nutrients and non-nutrients undergo microbial digestion in the lower GIT [22,23]. In turn, the total activity of enzymes composed of extra- and intracellular activities reflected the type and counts of bacterial species present in the digesta. In the present experiment, the modulatory effects of the dietary application of lactoferrin and the AMPs (melittin and cecropin A) on bacterial $\alpha$-glucosidase, $\beta$-glucosidase and $\beta$-glucuronidase were thoroughly scrutinised for 15 days, of which the first five days were the period of dietary AMP addition. The total, extracellular and intracellular activities of these enzymes quickly decreased, on average, after two days of AMP application, while the highest activity drop was noted on the last day (day 5) of dietary peptide administration and lasted for the next two to three days. It has been reported that AMPs lower bacterial counts through a variety of mechanisms, including membrane disruption, interference with bacterial metabolism, and through targeting cytoplasmic components [1]. The reduced total activity of faecal bacterial enzymes upon application of AMPs should be ascribed to both lowered bacterial count and depressed metabolic activity of microbes in the faecal digesta. Interestingly, the diminished activity of $\alpha$-glucosidase, $\beta$-glucosidase and $\beta$-glucuronidase caused by the dietary presence of cecropin A was additionally accompanied by a decreased rate of enzyme release from bacterial cells into the faecal environment. Such an effect was almost absent in the case of dietary supplementation with lactoferrin and melittin. It is well known that AMPs can change the permeability of the cell membrane, but different action mechanisms have been proposed, including barrel-stave, carpet, toroidal-pore and others [24]. The precise antibacterial action of cecropin A is still undiscovered, although recent work by Yun and Lee [25] showed that cecropin A-induced apoptotic activity was regulated by an ion imbalance and glutathione antioxidant system. Lee et al. [26] provided a new insight into the in vitro cecropin A mechanism of action with the aid of mouse macrophage-derived cells stimulated with lipopolysaccharides (LPS). Those authors observed that the antibacterial activity of cecropin A towards multidrug-resistant Gram-negative Acinetobacter baumanii and Pseudomonas aeruginosa was much higher than that of melittin. They also showed lower hemolytic activity and cytotoxicity of cecropin A compared to melittin, the latter in relation to their minimal inhibitory concentration (MIC). As opposed to melittin, cecropin A was found to be profoundly selective for the above-mentioned multidrug-resistant bacterial cells in the test with negatively charged and zwitterionic phospholipid vesicles, which mimic the Gram-negative bacterial and mammalian cell membranes, respectively [26]. Those differences between cecropin A and melittin might help explain the decreased rate of enzyme release from bacterial cells into the faecal environment in the CR rats observed in the present study. Additionally, a recent study conducted by Kalsy et al. [27] revealed a multi-target mechanism ascribed to antimicrobial peptide cecropin A entailing the pore-forming activity, inhibition of ef- 
flux pump activity and interactions with extracellular/intracellular nucleic acids. Wu et al. [1] reported that dietary supplementation with cecropin A beneficially alleviated enterotoxigenic Escherichia coli-induced piglet diarrhoea. Of paramount importance is the fact that Gram-negative bacteria have the presence of LPS on their cell surface, which are responsible for inflammatory reactions and septic shock in the host. In that regard, it has been observed that enhanced activity of bacterial $\beta$-glucuronidase followed the undesired growth of Escherichia coli and Clostridium intestinal populations [28]. $\beta$-Glucuronidase is involved in the generation of toxic and potentially harmful metabolites in the hindgut [29]. Regarding the accepted hypothesis, the CR treatment caused the highest drop in faecal $\beta$-glucuronidase activity, with the maximum drop noted on days 5 and 6 . The decreased $\beta$-glucuronidase activity persisted until day 10 in all three AMP groups, but again, the CR faeces were characterised by their lowest total activity.

The substrates of bacterial glycolytic enzymes and the functional and health implications of their products have been extensively researched [30,31]. For example, $\alpha$-glucosidase activities can improve fermentation of resistant starch, leading to the production of SCFAs and lactic acids, which are a source of energy for both the intestinal microbial community and the host tissues [32]. In contrast to glucoamylases (glucan 1,4- $\alpha$-glucosidases), $\alpha$ glucosidases favour oligosaccharides as substrates, while polysaccharides are hydrolysed relatively slowly or not at all. Numerous $\alpha$-glucosidases from bacteria and eukaryotes have been characterised, and the majority of them have been from mesophilic organisms [33]. In the present study, the diminished activity of faecal $\alpha$-glucosidase was comparable in the LF and MT groups. Similar to the case of bacterial $\beta$-glucuronidase, the strongest effect on $\alpha$-glucosidase activity followed the CR treatment and lasted until day 10, as indicated by decreased extracellular activity and enzyme release percentage. These findings are surprising to some extent considering that cecropin A is commonly used as a template for peptide molecular hybrids (such as melittin) to enhance the antibacterial activity of AMPs and reduce cell toxicity [6,34]. The effects of treatment with cecropin A were not only the strongest vs. melittin and lactoferrin but also the fastest, as manifested by decreased $\beta$-glucosidase activity on day 1 . Dosler et al. [35] reported the bactericidal effect of melittin within $2-7 \mathrm{~h}$ when tested against Pseudomonas aeruginosa, Escherichia coli and Klebsiella pneumoniae. Ferre et al. [36] showed high synergistic effects of the membrane actions of a cecropin-melittin antimicrobial hybrid peptide BP100, but Leandro et al. [37] did not observe enhanced antimicrobial activity of melittin-phospholipase A2 combinatory use in comparison to melittin alone. In the present study, we compared the action of melittin and cecropin A from insects with that of the well-known antimicrobial protein, namely lactoferrin. Lactoferrin has bacteriostatic properties against Escherichia coli, Staphylococcus aureus, Listeria monocytogenes and Bacillus species and strong action against the formation of biofilms. Some authors reported that infant formula containing LF promoted the growth of beneficial microbiota, such as Bifidobacteria and reduced the growth of Clostridium in the gut of infants [13].

The activity of $\beta$-glucosidase is associated with NSP hydrolysis and degradation of cellulose [38]. Moreover, the changes in $\beta$-glucosidase activity are more ambiguous because this hydrolytic activity is responsible for both the generation of toxins and the production of bacterial glucoside derivatives, which are assumed to be responsible for protection against chemically induced cancer [39]. In this regard, $\beta$-glucosidase activity is strongly involved in large gut polyphenol metabolism. It is well known that polyphenols are commonly present in plant foods as a bound form, most often conjugated as glycosides, and mainly metabolised by the gut microbiota, resulting in the formation of biologically active aglycones [40]. According to the literature, in addition to a wide range of other species, $\beta$-glucosidases are effectively produced by the probiotic bacteria Bifidobacterium and Lactobacillus [41]. However, it has been reported that the number of alkali-tolerant intestinal bacteria ( $1 \%$ of the total microbiota in humans and $0.8 \%$ of the microbiota in rats) is characterised by high synthesis of both $\beta$-glucosidase and $\beta$-glucuronidase. The $\beta$-glucosidase and $\beta$-glucuronidase activity of these intestinal bacteria is induced 
by elevating the $\mathrm{pH}$ of the medium (the enzyme activity in a medium of $\mathrm{pH} 7$ is 5 - to 10-fold higher than that in a medium of $\mathrm{pH}$ 6), but the growth is not changed [42]. In our experiment, the dietary addition of $100 \mathrm{mg} / \mathrm{kg}$ lactoferrin, melittin or cecropin A caused a significant increase in faecal $\mathrm{pH}$ values vs. the control on day 2 (treatment LF), days 5-8 (all three AMPs) and day 10 (treatment CR). An increase in faecal pH accompanied by decreases in bacterial enzymatic activities, including $\beta$-glucosidase and $\beta$-glucuronidase activities, suggested that all applied AMPs efficiently limit the growth of detrimental bacteria at more alkali $\mathrm{pH}$ intestinal values. Interesting and promising results were obtained by Zhai and co-workers [6], who showed selective enrichment of caecal Lactobacillus followed by intraperitoneal injection of $15 \mathrm{mg} / \mathrm{kg}$ cecropin A into C57BL/ 6 mice with DSS-induced IBD. Those authors observed that both cecropin A and the antibiotic gentamicin effectively reduced the number of caecal Bacteroidaceae and Enterobacteriaceae, but the action towards Lactobacillus was entirely different.

The observed faecal $\mathrm{pH}$ rise itself was not an unexpected result considering that decreased metabolic activity of intestinal microbiota, especially extracellular enzymatic activity, resulted in lowered SCFA concentrations. The acidity of intestinal contents is determined by various factors, including SCFA and ammonia concentrations, as well as the buffering capacity of the digesta. It has been reported that buffering capacity and SCFA concentrations are variables of paramount importance, whereas ammonia concentration is only slightly positively related to large gut $\mathrm{pH}$ values $[43,44]$. The latter statement about the intraluminal ammonia level and its effect on intestinal $\mathrm{pH}$ corroborates our results, as a large decrease in faecal ammonia exerted by LF, MT and CR, e.g., on days 6-8, did not lead to an acidifying effect in the faeces.

\section{Conclusions}

The results suggested that the faecal intensity of microbial fermentation processes in rats was quickly reduced upon dietary addition of the AMPs lactoferrin, melittin or cecropin A at a dosage of $100 \mathrm{mg} / \mathrm{kg}$ after two days of treatment, on average. Considering that the rats were subjected to AMPs for 5 days, the strongest suppression effect was observed on the last day of treatment and persisted on days $5-8$. The changes caused by the supplemented AMPs were reversible after 15 days, i.e., 10 days after the withdrawal of the AMPs from the diet. While the observed suppression effect on microbial fermentation processes is intended to be maintained, the dietary continuous presence of AMPs ought to be considered as nutritionally advisable, otherwise gut microbiota are likely to return to their pre-supplementation condition. The strongest decrease in bacterial $\beta$-glucosidase and $\beta$-glucuronidase activities as well as diminished SCFA and ammonia concentrations in the faeces were observed in rats fed a diet supplemented with cecropin A. The mechanism of suppressed microbial fermentation involved a diminished release of enzymes from bacterial cells to the faecal digesta only in the case of cecropin A. In this context our next experiment will be dedicated to very intriguing hypothesis driven by Ramin and Allison [45] that bacteria display three "behaviour" strategies, namely (i) investment in extracellular enzyme production, (ii) investment in high growth rates, or (iii) the struggle for survival with a low potential for enzyme production and growth.

Author Contributions: Conceptualization, J.J., A.R., M.M., B.F. and Z.Z.; formal analysis, J.J., A.R. and M.M.; funding acquisition, J.J. and Z.Z.; investigation, J.J., A.R., M.M. and B.F.; methodology, J.J. and M.M.; resources, A.R. and Z.Z.; visualization, J.J. and B.F.; writing-original draft, J.J., B.F., A.R. and M.M.; writing-review and editing, J.J. and Z.Z. All authors have read and agreed to the published version of the manuscript.

Funding: This research received no external funding.

Institutional Review Board Statement: The animals were used in compliance with the European Guidelines for the Care and Use of Laboratory Animals [Directive 2010/63/EU of the European Parliament and of the Council of 22 September 2010 on the protection of animals used for scientific purposes. Official Journal of the European Union 2010, L 276, 20.10.2010, pp. 33-79]. The experimental 
protocol was permitted by the Local Animal Care and Use Committee (Approval No. 34/2019; Olsztyn, Poland).

Data Availability Statement: Data is available from the corresponding author upon reasonable request.

Conflicts of Interest: The authors declare no conflict of interest.

\section{References}

1. Wu, S.; Zhang, F.; Huang, Z.; Liu, H.; Xie, C.; Zhang, J.; Thacker, P.A.; Qiao, S. Effects of the antimicrobial peptide cecropin AD on performance and intestinal health in weaned piglets challenged with Escherichia coli. Peptides 2012, 35, 225-230. [CrossRef] [PubMed]

2. Kumar, P.; Kizhakkedathu, J.N.; Straus, S.K. Antimicrobial Peptides: Diversity, Mechanism of Action and Strategies to Improve the Activity and Biocompatibility In Vivo. Biomolecules 2018, 8, 4. [CrossRef] [PubMed]

3. Bulet, P. Insect Antimicrobial Peptides: Structures, Properties and Gene Regulation. Protein Pept. Lett. 2005, 12, 3-11. [CrossRef] [PubMed]

4. Brady, D.; Grapputo, A.; Romoli, O.; Sandrelli, F. Insect Cecropins, Antimicrobial Peptides with Potential Therapeutic Applications. Int. J. Mol. Sci. 2019, 20, 5862. [CrossRef] [PubMed]

5. Andrä, J.; Berninghausen, O.; Leippe, M. Cecropins, antibacterial peptides from insects and mammals, are potently fungicidal against Candida albicans. Med. Microbiol. Immunol. 2001, 189, 169-173. [CrossRef]

6. Zhai, Z.; Zhang, F.; Cao, R.; Ni, X.; Xin, Z.; Deng, J.; Wu, G.; Ren, W.; Yin, Y.; Deng, B. Cecropin A Alleviates Inflammation Through Modulating the Gut Microbiota of C57BL/6 Mice With DSS-Induced IBD. Front. Microbiol. 2019, 10, 1595. [CrossRef]

7. Socarras, K.M.; Theophilus, P.A.S.; Torres, J.P.; Gupta, K.; Sapi, E. Antimicrobial Activity of Bee Venom and Melittin against Borrelia burgdorferi. Antibiotics 2017, 6, 31. [CrossRef]

8. Yi, H.-Y.; Chowdhury, M.; Huang, Y.-D.; Yu, X.-Q. Insect antimicrobial peptides and their applications. Appl. Microbiol. Biotechnol. 2014, 98, 5807-5822. [CrossRef]

9. Ongey, E.L.; Pflugmacher, S.; Neubauer, P. Bioinspired Designs, Molecular Premise and Tools for Evaluating the Ecological Importance of Antimicrobial Peptides. Pharmaceuticals 2018, 11, 68. [CrossRef]

10. Cholewińska, E.; Ognik, K.; Fotschki, B.; Zduńczyk, Z.; Juśkiewicz, J. Comparison of the effect of dietary copper nanoparticles and one copper (II) salt on the copper biodistribution and gastrointestinal and hepatic morphology and function in a rat model. PLOS ONE 2018, 13. [CrossRef]

11. Gugołek, A.; Juśkiewicz, J.; Strychalski, J.; Konstantynowicz, M.; Zwoliński, C. Nutrient digestibility and colonic fermentation processes in species of the families Mustelidae and Canidae fed the same diet. J. Exp. Zool. Part A Ecol. Genet. Physiol. 2015, 323, 637-644. [CrossRef]

12. Jenssen, H.; Hancock, R.E. Antimicrobial properties of lactoferrin. Biochimie 2009, 91, 19-29. [CrossRef]

13. Krzyżek, P.; Paluch, E.; Gościniak, G. Synergistic Therapies as a Promising Option for the Treatment of Antibiotic-Resistant Helicobacter pylori. Antibiotics 2020, 9, 658. [CrossRef]

14. Directive 2010/63/EU of the European Parliament and of the Council of 22 September 2010 on the Protection of Animals Used for Scientific Purposes. Official Journal of the European Union 2010, L 276, 20.10.2010, pp. 33-79. Available online: https:/ / eur-lex.europa.eu/LexUriServ/LexUriServ.do?uri=OJ:L:2010:276:0033:0079:en:PDF (accessed on 31 March 2021).

15. Reeves, P.G. Components of the AIN-93 Diets as Improvements in the AIN-76A Diet. J. Nutr. 1997, 127, 838S-841S. [CrossRef]

16. Wang, J.; Hihara, E. A unified formula for calculating body surface area of humans and animals. Graefes Arch. Clin. Exp. Ophthalmol. 2004, 92, 13-17. [CrossRef]

17. Hofírek, B.; Haas, D. Comparative Studies of Ruminal Fluid Collected by Stomach Tube or by Puncture of the Caudoventral Ruminal Sac. Acta Vet. Brno 2001, 70, 27-33. [CrossRef]

18. Fotschki, B.; Juśkiewicz, J.; Jurgoński, A.; Kołodziejczyk, K.; Milala, J.; Kosmala, M.; Zduńczyk, Z. Anthocyanins in Strawberry Polyphenolic Extract Enhance the Beneficial Effects of Diets with Fructooligosaccharides in the Rat Cecal Environment. PLoS ONE 2016, 11. [CrossRef]

19. Tang, J. Microbial Metabolomics. Curr. Genom. 2011, 12, 391-403. [CrossRef]

20. Hillman, E.T.; Lu, H.; Yao, T.; Nakatsu, C.H. Microbial Ecology along the Gastrointestinal Tract. Microbes Environ. 2017, 32, 300-313. [CrossRef]

21. Żary-Sikorska, E.; Kosmala, M.; Milala, J.; Fotschki, B.; Ognik, K.; Juśkiewicz, J. Concentrations of Blood Serum and Urinal Ellagitannin Metabolites Depend Largely on the Post-Intake Time and Duration of Strawberry Phenolics Ingestion in Rats. Pol. J. Food Nutr. Sci. 2019, 69, 379-386. [CrossRef]

22. Gugołek, A.; Juśkiewicz, J.; Strychalski, J.; Zwoliński, C.; Żary-Sikorska, E.; Konstantynowicz, M. The effects of rapeseed meal and legume seeds as substitutes for soybean meal on productivity and gastrointestinal function in rabbits. Arch. Anim. Nutr. 2017, 71, 311-326. [CrossRef]

23. Konieczka, P.; Szkopek, D.; Kinsner, M.; Fotschki, B.; Juśkiewicz, J.; Banach, J. Cannabis-derived cannabidiol and nanoselenium improve gut barrier function and affect bacterial enzyme activity in chickens subjected to C. perfringens challenge. Vet. Res. 2020, 51, 1-14. [CrossRef] 
24. Mylonakis, E.; Podsiadlowski, L.; Muhammed, M.; Vilcinskas, A. Diversity, evolution and medical applications of insect antimicrobial peptides. Philos. Trans. R. Soc. B Biol. Sci. 2016, 371, 20150290. [CrossRef]

25. Yun, J.; Lee, D.G. Cecropin A-induced apoptosis is regulated by ion balance and glutathione antioxidant system in Candida albicans. IUBMB Life 2016, 68, 652-662. [CrossRef]

26. Lee, E.; Shin, A.; Kim, Y. Anti-inflammatory activities of cecropin a and its mechanism of action. Arch. Insect Biochem. Physiol. 2014, 88, 31-44. [CrossRef]

27. Kalsy, M.; Tonk, M.; Hardt, M.; Dobrindt, U.; Zdybicka-Barabas, A.; Cytrynska, M.; Vilcinskas, A.; Mukherjee, K. The insect antimicrobial peptide cecropin A disrupts uropathogenic Escherichia coli biofilms. NPJ Biofilms Microbiomes 2020, 6, 1-8. [CrossRef]

28. Klewicka, E.; Nowak, A.; Zduńczyk, Z.; Juśkiewicz, J.; Cukrowska, B. Protective effect of lactofermented red beetroot juice against aberrant crypt foci formation, genotoxicity of fecal water and oxidative stress induced by 2-amino-1-methyl-6-phenylimidazo[4,5b] pyridine in rats model. Environ. Toxicol. Pharmacol. 2012, 34, 895-904. [CrossRef]

29. Pellock, S.J.; Creekmore, B.C.; Walton, W.G.; Mehta, N.; Biernat, K.A.; Cesmat, A.P.; Ariyarathna, Y.; Dunn, Z.D.; Li, B.; Jin, J.; et al. Gut Microbial $\beta$-Glucuronidase Inhibition via Catalytic Cycle Interception. ACS Cent. Sci. 2018, 4, 868-879. [CrossRef] [PubMed]

30. Nagpal, R.; Wang, S.; Woods, L.C.S.; Seshie, O.; Chung, S.T.; Shively, C.A.; Register, T.C.; Craft, S.; McClain, D.A.; Yadav, H. Comparative Microbiome Signatures and Short-Chain Fatty Acids in Mouse, Rat, Non-human Primate, and Human Feces. Front. Microbiol. 2018, 9, 2897. [CrossRef]

31. Richardson, A.J.; McKain, N.; Wallace, R.J. Ammonia production by human faecal bacteria, and the enumeration, isolation and characterization of bacteria capable of growth on peptides and amino acids. BMC Microbiol. 2013, 13, 6. [CrossRef]

32. Cerqueira, F.M.; Photenhauer, A.L.; Pollet, R.M.; Brown, H.A.; Koropatkin, N.M. Starch Digestion by Gut Bacteria: Crowdsourcing for Carbs. Trends Microbiol. 2020, 28, 95-108. [CrossRef] [PubMed]

33. Angelov, A.; Putyrski, M.; Liebl, W. Molecular and Biochemical Characterization of $\alpha$-Glucosidase and $\alpha$-Mannosidase and Their Clustered Genes from the Thermoacidophilic Archaeon Picrophilus torridus. J. Bacteriol. 2006, 188, 7123-7131. [CrossRef] [PubMed]

34. Rai, A.; Pinto, S.; Evangelista, M.B.; Gil, H.; Kallip, S.; Ferreira, M.G.; Ferreira, L. High-density antimicrobial peptide coating with broad activity and low cytotoxicity against human cells. Acta Biomater. 2016, 33, 64-77. [CrossRef] [PubMed]

35. Dosler, S.; Karaaslan, E.; Gerceker, A.A. Antibacterial and anti-biofilm activities of melittin and colistin, alone and in combination with antibiotics against Gram-negative bacteria. J. Chemother. 2016, 28, 95-103. [CrossRef] [PubMed]

36. Ferre, R.; Melo, M.N.; Correia, A.D.; Feliu, L.; Bardají, E.; Planas, M.; Castanho, M. Synergistic Effects of the Membrane Actions of Cecropin-Melittin Antimicrobial Hybrid Peptide BP100. Biophys. J. 2009, 96, 1815-1827. [CrossRef]

37. Leandro, L.F.; Mendes, C.A.; Casemiro, L.A.; Vinholis, A.H.; Cunha, W.R.; De Almeida, R.; Martins, C.H. Antimicrobial activity of apitoxin, melittin and phospholipase A2 of honey bee (Apis mellifera) venom against oral pathogens. An. Acad. Bras. Cienc. 2015, 87, 147-155. [CrossRef]

38. Zduńczyk, Z.; Jankowski, J.; Mikulski, D.; Juśkiewicz, J.; Slominski, B. The effect of NSP-degrading enzymes on gut physiology and growth performance of turkeys fed soybean meal and peas-based diets. Anim. Feed. Sci. Technol. 2020, 263, 114448. [CrossRef]

39. Gugołek, A.; Juśkiewicz, J.; Kowalska, D.; Zwoliński, C.; Sobiech, P.; Strychalski, J. Physiological responses of rabbits fed with diets containing rapeseed meal, white lupine and pea seeds as soybean meal substitutes. Ciênc. Agrotec. 2018, 42, 297-306. [CrossRef]

40. Michlmayr, H.; Kneifel, W. $\beta$-Glucosidase activities of lactic acid bacteria: Mechanisms, impact on fermented food and human health. FEMS Microbiol. Lett. 2014, 352, 1-10. [CrossRef]

41. Strahsburger, E.; De Lacey, A.M.L.; Marotti, I.; Digioia, D.; Biavati, B.; Dinelli, G. In vivo assay to identify bacteria with $\beta$-glucosidase activity. Electron. J. Biotechnol. 2017, 30, 83-87. [CrossRef]

42. Kim, D.; Kang, H.; Park, S.; Kobashi, K. Characterization of .BETA.-Glucosidase and .BETA.-Glucuronidase of Alkalotolerant Intestinal Bacteria. Biol. Pharm. Bull. 1994, 17, 423-426. [CrossRef]

43. De Blas, C.; García, J.; Carabaño, R. Role of fibre in rabbit diets. A review. Anim. Res. 1999, 48, 3-13. [CrossRef]

44. Ilhan, Z.E.; Marcus, A.K.; Kang, D.-W.; Rittmann, B.E.; Krajmalnik-Brown, R. pH-Mediated Microbial and Metabolic Interactions in Fecal Enrichment Cultures. mSphere 2017, 2. [CrossRef]

45. Ramin, K.I.; Allison, S.D. Bacterial Tradeoffs in Growth Rate and Extracellular Enzymes. Front. Microbiol. 2019, 10, 2956. [CrossRef] 